\title{
Initializing Startups In Engineering And Technology Institutions
}

\author{
Indra Prakash Mishra ${ }^{1}$, Nishith Dubey ${ }^{2}$, \\ ${ }^{1} U$ P Textile Technology Institute, Kanpur, India \\ ${ }^{2, N i t t t r, ~ B h o p a l, ~ I n d i a ~}$
}

\begin{abstract}
India is striving on one side for increasing, consistent industrial growth and on the other side making efforts to overcome the problem of unemployment amongst engineering graduates. Though the economic growth is expected to be 4.4 per cent, the consistency is still not assured. In present scenario when developed countries, in spite of their high growth, are focusing on young entrepreneurs to create ecosystem for fostering their innovations. Owing to the high risk nature of the startups, there is need to address issues pertaining to conceive a venture covered under startups. These are government policies, ecosystem supporting startups, availability of technical, entrepreneurial support, funds and more importantly the education system to effectively impart entrepreneurship competency clusters. Here comes the role of a Technology or Engineering Institution, the Engineering Institutions need to be poised to create an enterprising society. Startups require a lot of creativity, motivation, inter-disciplinary skills, planning and team work. The present education system has not been designed to accomplish the same. The paper provides strategic changes required for engineering institutions and suggest measures to enable them to develop favorable ecosystem for startups.
\end{abstract}

\section{Introduction}

The peaks and crests of Indian Industrial growth can be grouped in four different phases First phase covering three Five-Year Plan periods 1951-1955, 1956-1960 and 1960-1965 witnessed the establishment of strong industrial base in the form of capital investment in iron and steel industries and heavy engineering and capital goods industries. Second phase between the years 1965-1980 includes fourth and fifth plan and observed the decline in average annual compound growth rate from $9.0 \%$ to $4.1 \%$ during 1965-1976 and eventually negative annual growth is recorded (-1.6 Percent) in 1978-79.Third Phase, from 1981 to 1991 was industrial recovery period with the annual rate of growth of industrial production 9.0 per cent in 1990-91 and Forth phase between 1991-1998 recorded the sharp retrogression in the country followed by an immediate upturn trend and recorded industrial growth as 8.6 percent in1997-98. In recent years, industrial growth declined from 8.2 percent in 2010-11 to 2.9 percent in 2011-12 and 1.8 percent in 12-13. The growth recorded negative $(-0.1 \%)$ in $2013-$ 14. Presently India is heading towards growth of 4.4 per cent in 2015-16. The often declining pattern in industrial growth may be linked with the entrepreneurship and in turn with the Startups when we seek improvements in Growth.

With the recent Flagship initiative of Government of India 'Startups-India', the entrepreneurship development is expected to take boom in coming years. Those who have innate entrepreneurial competencies and have a ready idea for execution can startup unquestioned. But there is one question "how many?" To achieve the expected growth we need to produce sufficiently more entrepreneurs rather than waiting for them to take birth with competencies. By now the belief that entrepreneurs cannot be created through education, teaching, training and counseling is faded out and is validated by the exhaustive experimental activities carried out by Prof David McClelland and other scholars. Now the large enterprises and various government agencies and public sector organizations are focusing on this aspect. The more important issue to be addressed is to develop the Entrepreneurship Competencies in the students of Engineering and Technological institutions before their leaving the institution.

\section{Understanding Startups}

The Term "Startups" is very much in use for last few years to describe young scrappy ventures with some innovative idea of new product or service or potential value enhancement in existing product or services. However startups need to be looked into greater details.

\section{A. Startups}

Startup in context of business model is the transition stage in the life cycle of technology oriented business venture when an innovative idea is converted into venture with high risk of failure but with potential of high scalability. Eric Ries (Entrepreneur-in-residence at Harvard Business School ) defines Startup as "A human institution designed to deliver a new product or service under conditions of extreme uncertainty" Definition of startup in the context of business. Forbes unveiled another definition quoting Neil Blumenthal, cofounder and 
co-CEO of Warby Parker as "A startup is a company working to solve a problem where the solution is not obvious and success is not guaranteed." [1]

\section{B. Process of Startups}

1) Maturing the Idea: At the first step feasibility study of implementation of the idea which funned out after rigorous brain storming, is to be carried out. A project Plan is to be made and analyzed for technical viability, reasoning of estimated costs and cost benefits. Market segmentation at this stage may be done on the basis of Geography, Demographics, Psychographics, Benefits sought, Usage rate etc but this may not be weighed while funneling out the minimum viable product.

2) Pilot venture: Next step is to startup a pilot venture with the minimum viable funding. The funding at this stage is suggested through traditional sources as family, private small financial institutions or through incubators. Government of India in its Action Plan 2016 for Startups addressed the issue and supported establishments of Incubation center at 10 selected Institutes of repute.

\section{3) Funding:}

Level-I Funding: By Angel Investors; an angel investor is an investor who provides financial backing for small startups or entrepreneurs. Angel investors are usually found among an entrepreneur's family and friends. The capital they provide can be a one-time injection of seed money or ongoing support to carry the company through difficult times [2].

Level-II Funding: By Venture Capitals; Private investors, who provide venture capital to business ventures which are promising. They typically invest where at least 25 percent annual returns within one to five years are feasible, and often demand 50 percent or more ownership to exercise control over the investee firm to offset their high risk. Often they also provide management and industry expertise and business connections with other firms and venture capitalists. Their objective usually is to bring the business in its initial public offer (IPO) stage so that they can sell their shareholdings to the public at high profit and get out [3]. Once pilot project becomes attractive enough to potential investors it may get the required fund on the basis of business plan and the power to show the growth. The following is the investment data of recent funding received by Indian startups.

Table 1 Investment in Indian startups in 2015

\begin{tabular}{|l|l|}
\hline Investor / VC & Investment in Indian startups \\
\hline Tiger Global Management & $\$ 422$ million \\
\hline Russian investor Yuri Milner-led DST Global & $\$ 352$ million \\
\hline Japanese telecom giant Softbank & $\$ 282$ million \\
\hline VC firm Nexus Venture Partners & $\$ 73$ million \\
\hline Kalaari Capital with \$45 million in six deals & $\$ 45$ million \\
\hline VC firm Sequoia Capital & $\$ 208$ million \\
\hline Accel Partners & $\$ 0.5-50$ million \\
\hline
\end{tabular}

\section{4) Support System for Startups}

Promoting Agencies; There are agencies which are formed under the aegis of Government of India and several other organizations are poised to support entrepreneurship in India. Some of the agencies are like National Entrepreneurship Network (NEN), The Indus Entrepreneurs (TIE) and Department of Industrial Policy and Promotion, (DIPP) under the aegis of Ministry of Commerce and Industry are in practice of providing support to the Startups.

Funding Agencies; The Startups are primarily funded by innovators own saving or by funds from family and friends. However at the later stage higher fund requirement will arise. Angel Investors and VCs play an important role at later stages. There are a number of investors who funded Indian startup in 2015 as shown in Chart 1

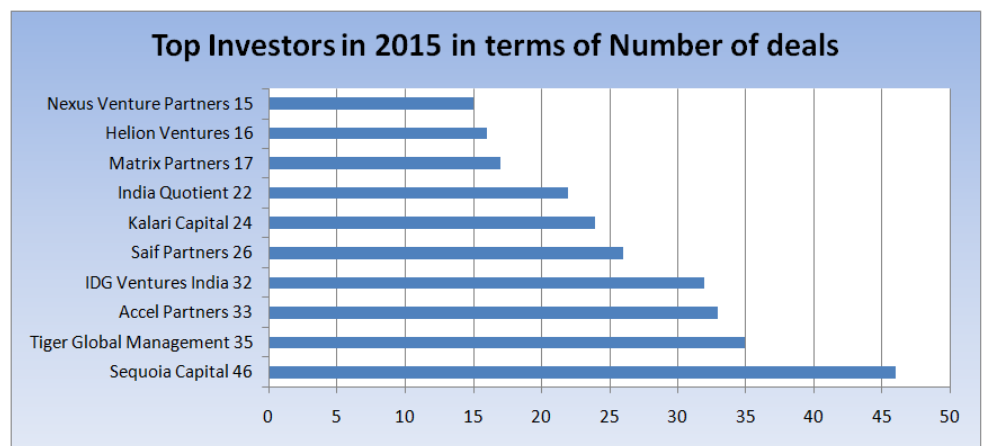

Chart 1- Top Investors in 2015 in terms of deals [4] 
Startup Platforms; the suggested startup platform is through incubators and entrepreneurship development Cells established within the Engineering Institute. Startup India Initiative of Government of India provides ecosystem for Startups but still suitable Platform is required. Industry sponsored projects schemes may serve the purpose.

\section{Some Examples of Startups:}

Zivame: "I realized that lingerie as a category in India is under-served. There is unavailability of sizes, social discomfort and very poor market penetration", says Richa Kar, CEO of Zivame.com who is taking the women's underwear market by storm. The freedom of choice and the sense of liberation that it has provided to its consumers is unmatched by traditional lingerie stores.

Redbus: It's incomprehensible to imagine now that there was nothing like RedBus for a long time despite the thriving existence of MakeMyTrip and Yatra. When an increasing number of consumers were booking tickets online for trains and flights, why were buses left out? This compelling question gave birth to RedBus, now acquired by the ibibo Group for \$138 Million.

Paytm: As India is one major consumer of mobile phones, this company capitalized on this opportunity and decided to revolutions the m-commerce in India. Its success is clear from the statistics. 15 million orders per month and boosting mobile wallets of 80 million people it is leader in its sector, providing services to big companies like Dominoz, Uber etc.

Ola:Ola (formerly Olacabs), in April 2015, announced raising $\$ 400$ million in its series E round of funding led by DST Global with participation from GIC, Falcon Edge Capital, and existing investors SoftBank Group, Tiger Global, Steadview Capital and Accel Partners US. From this amount, Ola has earmarked \$100 million towards fuelling expansion and growth of the acquired TaxiForSure. Through "Ola Pragati" in partnership with the State Bank of India, drivers can now avail of a daily loan repayment facility and a lower down payment to buy a car of their choice. Ola aims to offer this program to over 100,000 driver entrepreneurs across India within the next two years under its expansion program.

\section{Entrepreneurship Capability Building}

Entrepreneurship competency building is a long process because it is behavioral change. Many interventions of behavioral changes, included in teaching- learning process, will develop different competency clusters amongst the students. This process is intensive and integrated approach throughout the programme duration has to be followed. Various competency clusters have been identified:

Table 2. Various Entrepreneurial Competency Clusters

\begin{tabular}{|l|l|}
\hline Entrepreneurial Competencies \\
\hline Competencies Cluster & Associated Skills \\
\hline Achievement & Initiative \\
& observing \& acting on opportunities \\
& Persistence, Information seeking \\
& Concern for high quality of work \\
& Commitment to work contract \\
& Efficiency orientation \\
\hline Thinking and Problem Solving & Systematic Planning, Problem Solving \\
\hline Personal Maturity & Self-confidence, Resilience, Risk Taking \\
\hline Influence & Persuasion, Use of influence strategy \\
\hline Directing \& Controlling & Assertiveness, Monitoring \\
\hline Values & Concern of others, Empathy, Honesty, \\
& Trustworthiness, accountability \\
\hline
\end{tabular}

Entrepreneurship capability building is to be exercised by technology and Engineering Institutions. The possible ways are training of Trainers to develop mindset and enterprising society. Curriculum development is essential part for developing entrepreneurship competency cluster amongst the students in consistent manner during the time span of degree programme.

\section{A. Training of Trainers or Faculty}

\section{Fostering Startup Culture In Technical Education}

Faculty is major stakeholder in imparting Entrepreneurship Competencies to the engineering students. There was need of designing some training modules for the faculty of engineering institutions with the interaction of stakeholders including consultants, field specialists, eminent educationists, students and successful entrepreneurs, for preparing Faculty who is ready to take the challenge of the national movement. Entrepreneurship Development Institute of India (EDI) has already designed a module on Faculty Development 
Programme (FDP) and has been implementing it successfully. They designed the course with objective to expose the participating faculty members to the comprehensive Entrepreneurship Development process and equip them to coordinate/ organize entrepreneurship related activities in their institutions. The module also aims at equipping them with requisite skills, knowledge and competencies for effective initiation of Entrepreneurship Awareness Camps, activities and creating Entrepreneurial and Enterprising culture in their institutions. There is no need to create or employ a management faculty for the purpose. Existing faculty can be easily trained to handle entrepreneurship development activity once he changes his mindset and gets some hands on training. The model fits only when outcome based teaching learning system is deployed effectively. The SWOT analysis for the faculty role in OBE is presented below in table 3 [5].

Table 3- SWOT analysis of faculty role in OBE for startup ecosystem.

\begin{tabular}{|c|c|c|c|}
\hline Strengths & Weaknesses & Opportunities & Threats \\
\hline $\begin{array}{l}\text { Outcomes-based learning and } \\
\text { assessment approaches comprise } \\
\text { effective mechanisms for } \\
\text { improving the educational } \\
\text { experiences of students and an } \\
\text { effective tool for faculty, } \\
\text { programs, and departments in } \\
\text { order to obtain better results in } \\
\text { terms of student learning for } \\
\text { their investment of time and } \\
\text { resources for problem } \\
\text { identification and generating } \\
\text { solutions for startup ecosystem. } \\
\text { OBE reflects a shift in language } \\
\text { and in power; in the social role } \\
\text { of higher learning; in learning as } \\
\text { public, explicit, and shared, and } \\
\text { as a communal enterprise } \\
\text { helping in extension services for } \\
\text { fulfilling social obligations. } \\
\text { Faculty determines the } \\
\text { appropriate learning strategies } \\
\text { and assessment strategies to } \\
\text { match the intended outcomes. } \\
\text { The faculty who volunteered to } \\
\text { participate because they believe } \\
\text { in outcomes-based education are } \\
\text { benefiting from their } \\
\text { collaboration and opportunities } \\
\text { to share creative strategies to } \\
\text { facilitate learning. }\end{array}$ & $\begin{array}{l}\text { It has been a challenge to } \\
\text { shift from individual } \\
\text { faculty work to } \\
\text { interdisciplinary faculty } \\
\text { teamwork which is } \\
\text { essential for startup } \\
\text { ecosystem. } \\
\text { A special challenge has } \\
\text { been compliance with } \\
\text { external regulations and } \\
\text { accreditation standards. } \\
\text { Faculty members are } \\
\text { unable to understand shift } \\
\text { to learning outcomes. } \\
\text { They spend more time in } \\
\text { teaching which may not } \\
\text { generate learning in } \\
\text { students. } \\
\text { Some faculty are afraid of } \\
\text { change because they may } \\
\text { feel the changes mean } \\
\text { someone wants to get rid } \\
\text { of their course or force } \\
\text { them to change their way } \\
\text { of teaching. }\end{array}$ & $\begin{array}{l}\text { Many of the faculty } \\
\text { believes, however, that the } \\
\text { implementation of learning } \\
\text { outcomes approaches will } \\
\text { lead to greater efficiency } \\
\text { and quality in teaching and } \\
\text { learning; but for faculty } \\
\text { this shift takes a leap of } \\
\text { faith. } \\
\text { No specific model of } \\
\text { outcomes-based education } \\
\text { was championed, and the } \\
\text { faculty was free to } \\
\text { determine how OBE would } \\
\text { be designed for startup } \\
\text { ecosystem. } \\
\text { Focus on outcomes can } \\
\text { lead to considerable } \\
\text { savings of a faculty } \\
\text { member's time and effort, } \\
\text { to instruction that is better } \\
\text { geared to the student's } \\
\text { preparedness without loss } \\
\text { of standards, and } \\
\text { ultimately to greater } \\
\text { learning. } \\
\text { Work hard to develop a } \\
\text { culture of civility, respect } \\
\text { and collaboration for } \\
\text { developing professional } \\
\text { teaching. } \\
\text { Be able to call upon shared } \\
\text { commitments and values to } \\
\text { get you through some of } \\
\text { the rough spots. }\end{array}$ & $\begin{array}{l}\text { The belief that a shift to an } \\
\text { outcomes-based nution } \\
\text { environment might normalize } \\
\text { the educational experience of } \\
\text { students or reduce learning to its } \\
\text { lowest common denominator, } \\
\text { produce a mechanistic view of } \\
\text { teaching and learning and } \\
\text { oversimplify the very complex } \\
\text { and nuanced learning processes } \\
\text { that this requires. } \\
\text { Some resistance to outcomes- } \\
\text { based approaches despite the } \\
\text { fact that the University is } \\
\text { dedicated to teaching as well as } \\
\text { research. } \\
\text { A prior condition for a shift to } \\
\text { learning outcomes education is } \\
\text { an understanding of faculty's } \\
\text { time and their expectations } \\
\text { about time. } \\
\text { Disagreements over intended } \\
\text { outcomes and standards for assessment can } \\
\text { andivide the academic community } \\
\text { Disincentives, such as } \\
\text { promotion and tenure structures } \\
\text { that currently do not support this } \\
\text { kind of investment of faculty }\end{array}$ \\
\hline
\end{tabular}

\section{B. Incubation of Innovating Ideas}

Incubation centers are already available in various institutions of national importance. Potential institutions may apply for getting funds for establishment of Incubation Center with the government under various schemes, or may tie up with organizations which support Incubation Center. Alternatively Institutions may approach any recognized incubation center for fostering innovative ideas of enterprising students.

Table 4-Incubators and Accelerators across India [6]

\begin{tabular}{|l|l|l|l|l|l|}
\hline Delhi & Bangalore & Mumbai & Chennai & Kerala & Ahmadabad \\
\hline $\begin{array}{l}\text { Indian Angel } \\
\text { Network Incubator }\end{array}$ & $\begin{array}{l}\text { Microsoft } \\
\text { Accelerator }\end{array}$ & $\begin{array}{l}\text { SINE, IIT } \\
\text { Bombay }\end{array}$ & $\begin{array}{l}\text { The Startup } \\
\text { Center }\end{array}$ & The Startup Village & CIIE, IIM Ahmadabad \\
\hline The Hatch & Khosla Labs & $\begin{array}{l}\text { Venture } \\
\text { Nursery }\end{array}$ & RTBI, IIT Madras & TechnoPark, TBI & $\begin{array}{l}\text { NDBI, } \\
\text { Ahmadabad }\end{array}$ \\
\hline TBIU, IIT Delhi & $\begin{array}{l}\text { NSRCEL, IIM } \\
\text { Bangalore }\end{array}$ & Seedfarm & $\begin{array}{l}\text { Villgro, IIT } \\
\text { Madras }\end{array}$ & TBI, NIT Calicut & Comm. TBI,MICA \\
\hline Tlabs & Angel Prime & GSF & $\begin{array}{l}\text { TBI, } \\
\text { University }\end{array}$ & Anna & \\
\hline GSF & Kyron & UnLtd India & & & \\
\hline 5ideas & GSF & & & \\
\hline
\end{tabular}


Government, under Action Plan 2016 for Startups announced to launch National Initiative for Developing and Harnessing Innovations (NIDHI) through Innovation and Entrepreneurship Development Centers (IEDCs)

\section{Curriculum Development}

"Startup success can be engineered by following the process, which means it can be learned, which means it can be taught."- Eric Ries. Entrepreneurship education was conceived as standalone subject in the institutes of Higher Education. The subject was compulsory in some universities and elective in nature in others. As such, no formal training of Trainers and infrastructure for behavioral development existed. In fact the course on entrepreneurship could not be integrated with other domain subjects. There are few institutions like Entrepreneurship Development Institute of India (EDII), The National Institute for Entrepreneurship and Small Business Development (NIESBUD), The Centre for Entrepreneurship Development (CED), National Institute for Micro, Small and Medium Enterprises Skills Empowerment in Technology (NIMSME) etc. These institutes have been working for the entrepreneurship development and have their Training of Trainers Programmes. They also conduct EACs (Entrepreneurship Awareness Camps) and EDPs (Entrepreneurship Development Programmes).

As the outcome based education system started taking shape in Indian education scenario, it would be easier to develop curricula, integrating entrepreneurship development in each domain or core subject. The curricula should be designed with careful observation and brain storming with academicians, entrepreneurs, students, alumni and other stakeholders. The curriculum should inculcate inter-disciplinary approach, live industrial projects, industrial problem solving and most important the ways to change the mindsets.

Table 5- Traditional Vs Outcome based Curriculum [7]

\begin{tabular}{|l|l|}
\hline Traditional curriculum & OBE Curriculum \\
\hline Passive Learners & Active Learners \\
\hline Rote Learning & Critical Thinking \\
\hline Textbook/Workbook bound and teacher centered & $\begin{array}{l}\text { Learner-centered, teacher is facilitator, Teacher constantly uses } \\
\text { group work and team work to consolidate the new approach }\end{array}$ \\
\hline $\begin{array}{l}\text { Teachers responsible for learning; motivation depends upon } \\
\text { personality of teacher }\end{array}$ & $\begin{array}{l}\text { Learners take responsibility for learning, Students motivated by } \\
\text { constant feedback and affirmation of their worth }\end{array}$ \\
\hline Emphasis on What the teacher hopes to achieve & $\begin{array}{l}\text { Emphasis on outcomes- what the learner becomes and } \\
\text { understands. }\end{array}$ \\
\hline
\end{tabular}

\section{Conclusion}

Current technology is knowledge economy. The economy is going global day by day, transforming the world into a global village. Business model can go across the world due to this knowledge. There exists ample opportunities for developing new and unique business but they require lateral thinking and entrepreneurship competencies. To develop such orientation amongst engineering students, Outcome Based Education (OBE) is needed. OBE provides sufficient learning opportunities to the engineering students, for the development of knowledge, skills and attributes. Focus in OBE shifts from learning to doing, which is crux of entrepreneurship and startups. Engineering institutions have major role in creating favorable environment for startups. Major restructuring in terms of curriculum development, faculty training and infrastructural reforms like creation of inter-disciplinary laboratories, incubators and accelerators etc. the findings in this paper, if implemented, by a technical institute will definitely provide favorable ecosystem for startups.

\section{References}

[1]. http://www.forbes.com/sites/natalierobehmed/2013/12/16/what-is-a-startup/\#576283784c63

[2]. www.investopedia.com/terms/a/angelinvestor.asp

[3]. http://www.businessdictionary.com/definition/venture-capitalist.html\#ixzz40XqEZP67

[4]. Radhika P. Nair, Youstory research at http://yourstory.com/2016/01/top-investors-of-indian-startups-2015/, 2016

[5]. Bahar Mousavi Hejazi, Professor Katharine Janzen, Outcomes-Based Education (OBE): A Transformational Perspective on Quality and Mobility in Higher Education Community College Leadership Program OISE/U of T January 2011

[6]. http://inc42.com/resources/50-amazing-startups-incubators-and-incubators-in-india/

[7]. C2005 Booklet, Lifelong Learning for the $21^{\text {st }}$ Century (DOE1997c:6), 2005. 